\title{
Misassembly during Maintenance/Repair
}

National Cancer Institute

\section{Source}

National Cancer Institute. Misassembly during Maintenance/Repair. NCI Thesaurus. Code C133646.

Problem associated with incorrect assembly of the device or constituents during maintenance or repair. 